\title{
Reconstructing an ancient mining landscape: a multidisciplinary approach to copper mining at Skouriotissa, Cyprus
}

\author{
Vasiliki Kassianidou $^{1, *}$, Athos Agapiou ${ }^{2,3}$ \& Sturt W. Manning ${ }^{4,5}$ \\ ${ }^{1}$ Archaeological Research Unit, Department of History and Archaeology, University of Cyprus, Cyprus \\ ${ }^{2}$ Department of Civil Engineering and Geomatics, Cyprus University of Technology, Cyprus \\ ${ }^{3}$ Eratosthenes Centre of Excellence, Limassol, Cyprus \\ ${ }^{4}$ Department of Classics, and Cornell Institute of Archaeology and Material Studies, Cornell University, USA \\ ${ }^{5}$ The Cyprus Institute, Nicosia, Cyprus \\ * Author for correspondence: $₫$ v.kassianidou@ucy.ac.cy
}

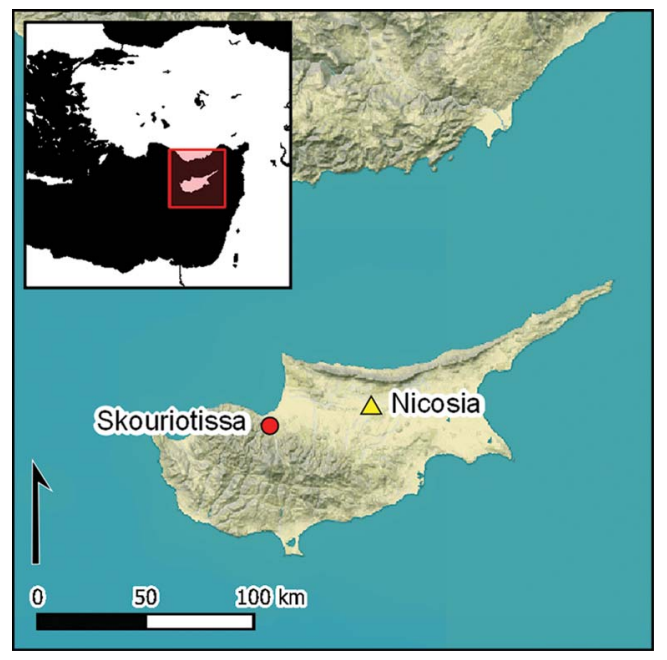

Extensively worked in antiquity, Skouriotissa remains the only active copper mine on the island of Cyprus. The modern, open-cast operation, however, has almost completely obliterated the earlier mining landscape. Here the authors report the results of investigations, including dating, of the ancient topography of the mine. They incorporate spatial data derived from archival sources, recent fieldwork and absolute dating into a geographical information system to reconstruct the ancient mining landscape around Skouriotissa. Their approach holds promise for understanding other mining regions in Cyprus and beyond, by providing an example of how diverse source material can be used to reconstruct landscapes now destroyed or buried by open-cast mining operations.

Keywords: Cyprus, Skouriotissa, ancient mining, copper, archaeometallurgy, GIS

\section{Introduction}

A number of recent studies have focused on the archaeological investigation of mining regions (see O'Brien (2015) and Table S1 in the online supplementary material (OSM)). Inspired by this work, the present article reports on the results of a project to reconstruct the ancient industrial and cultural landscape of the Skouriotissa copper mine on Cyprus, the island's last operating copper mine. Until recently, the archaeology of mining in general concentrated narrowly on mine workings (e.g. shafts and galleries) and on the associated technologies (e.g. Healy 1978). In the last few decades, however, the focus has widened. Stöllner

Received: 27 March 2020; Revised: 29 July 2020; Accepted: 6 August 2020

(C) The Author(s), 2021. Published by Cambridge University Press on behalf of Antiquity Publications Ltd. This is an Open Access article, distributed under the terms of the Creative Commons Attribution licence (http://creativecommons. org/licenses/by/4.0/), which permits unrestricted re-use, distribution, and reproduction in any medium, provided the original work is properly cited. 
(2014), for example, describes how the archaeology of mining now addresses a broader range of social, economic and landscape issues.

Despite the island's long established central place in histories of metal extraction and production (e.g. Muhly et al. 1982), only a handful of articles have been published on the ancient mines of Cyprus (e.g. Constantinou 1992a; Kassianidou 2000; also see the OSM). Moreover, some of these articles date to the early twentieth century (e.g. Bruce 1937), namely at a time when Cypriot archaeology generally and the archaeology of mining and archaeometallurgy specifically were not yet fully developed scientific disciplines. This lack of attention to mines on Cyprus is surprising, as the island was one of the most important sources of copper during antiquity (see the OSM) and, even today, it is considered to be one of the richest countries in copper by surface area (Constantinou 1982, 1992b).

In contrast to the lack of focus on the mines, there has been sustained scholarly interest in the archaeometallurgy of Cyprus - namely the phases in metal production related to the extraction of copper from ore and the production of metal artefacts. Hundreds of publications, along with two international conferences, have addressed copper production and the trade of Cypriot copper, especially during the second millennium BC (Muhly et al. 1982; Kassianidou \& Papasavvas 2012). The current project therefore aims to rebalance our knowledge by shifting the focus from smelting sites to the mines themselves. Skouriotissa is the obvious starting point; it was worked extensively in antiquity, especially during the late antique period (fourth to seventh centuries AD), when Byzantine exploitation reached a truly industrial scale. Nevertheless, we still lack much basic information.

Our project aims to record the history, archaeology and ancient environment of Skouriotissa, thus preserving an important facet of Cypriot cultural heritage that has been severely damaged by modern exploitation. Here, we report on one aspect of the project: the investigation of the ancient mining topography of the area, using a combination of spatial data derived from archival sources, recent fieldwork and absolute dating, the latter of which, in particular, begins to elucidate the site's pre-Byzantine history. These diverse, multi-temporal geo-data have been incorporated into a geographical information system (GIS), in order to reconstruct the ancient mining landscape, the physical remains of which have been almost completely obliterated by modern open-cast mining since the 1960s (Constantinou 1992b). The hills that once covered the rich cupriferous ore deposits and that were riddled with ancient mining galleries and adits (horizontal access passages) have been transformed into large artificial lakes. Only traces of the ancient mines remain, including segments of galleries observable in the sections of the open-cast pits, but often no longer accessible. Simultaneously, modern discard of crushed metal-poor waste has formed huge spoil heaps that cover and dominate the landscape in all mining regions of the island. The scale of the disturbance is evident from aerial and satellite photographs. Based on highresolution satellite images, the size of the disturbed area at Skouriotissa is estimated at approximately $500 \mathrm{ha}$ (Figure 1). To understand the pre-modern mining landscape and the topography around Skouriotissa it is necessary to turn to the information recorded in historical accounts, reports, maps, photographs and aerial photographs that pre-date the open-cast operations.

(C) The Author(s), 2021. Published by Cambridge University Press on behalf of Antiquity Publications Ltd 


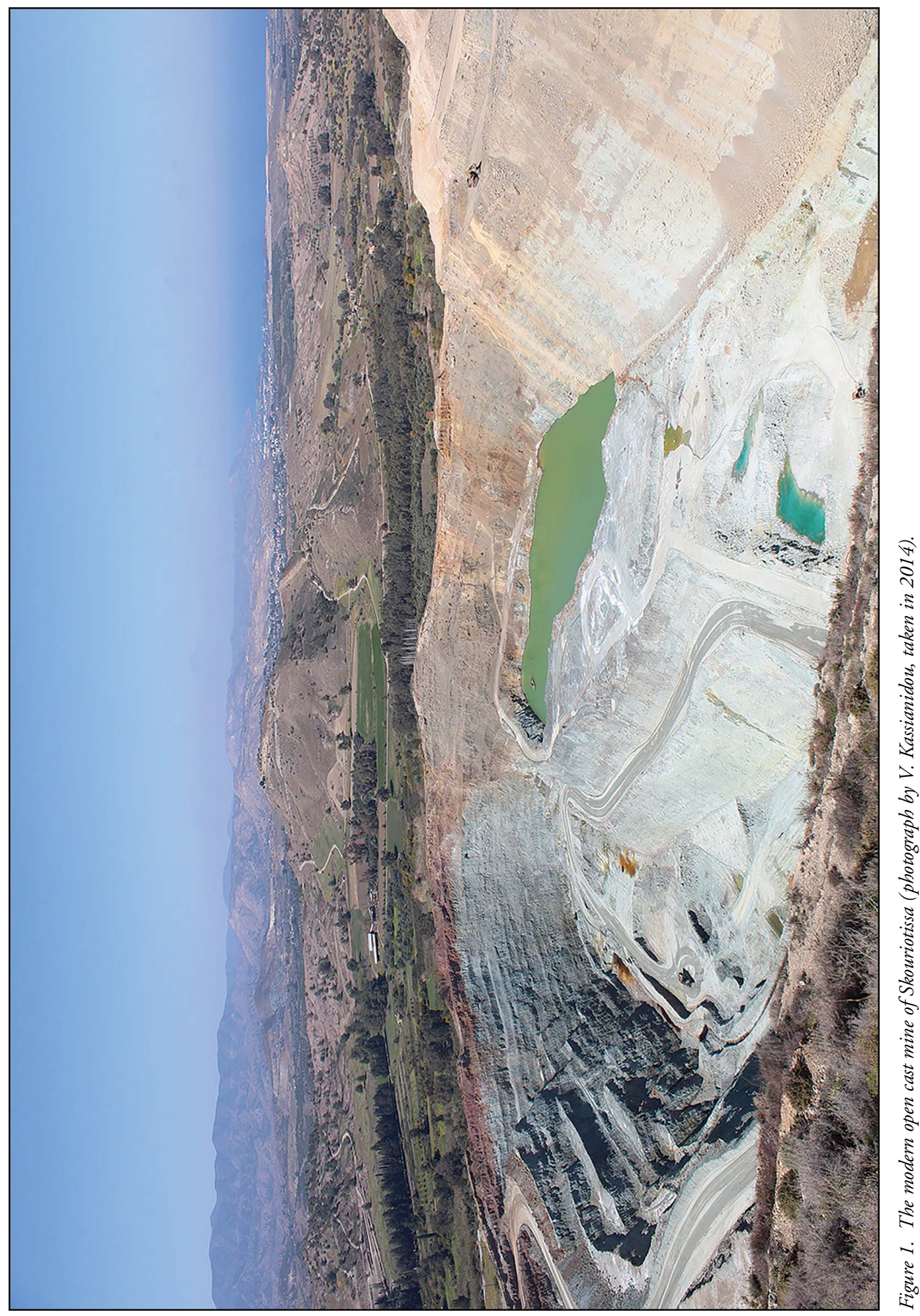

(C) The Author(s), 2021. Published by Cambridge University Press on behalf of Antiquity Publications Ltd 


\section{Skouriotissa and the Solea mining district}

The largest and richest ore deposits on Cyprus are located in the Solea Valley and mining district (Ingham 1959; Constantinou 1982). Here, the major mines are Mavrovouni, Apliki, Ambelikou and Skouriotissa (Figure 2) (see the OSM). The name of the area derives from a small church — once part of a monastery_-dedicated to Panagia Skouriotissa. Panagia is a title for the Virgin Mary in the Greek Orthodox church, and Skoria, or skouria, is the Greek word for slag. Thus, the church is dedicated to the 'Virgin Mary of the Slag'. This is no coincidence: the church is overshadowed by the largest slag heap on Cyprus-declared an ancient monument by the Department of Antiquities of the Republic of Cyprus, due both to its sheer size and because its associated mine is the only one specifically mentioned in ancient textual sources. In a fragmentary treatise attributed to Pseudo Aristotle (Cod. gr. Paris. 1310 f. 444; Wallace \& Orphanides 1990: 54), it is stated that "Boukasa is a mountain with gold mines and is situated at the foot of the Troodos toward the northern parts of the island and in relation to the sea, it is on the west". 'Boukasa' can only be 'Phoukasa', the hill rich in copper ore near Panagia Skouriotissa and the ancient slag heap. The combination of the hill, church and slag heap are also recorded on the first triangulated map of Cyprus prepared by Kitchener for the British Colonial government between 1878 and 1883 (Shirley 2001; see the OSM).

\section{Skouriotissa in pre-twentieth century travellers' accounts}

References to the Solea Valley mines can be found in travellers' accounts from the eighteenth century AD onwards. Some allow the identification of Skouriotissa through explicit reference to the association of the mines, slag heaps and the church. As iron oxides cover the copper ore deposits, and because some of the slag has a rusty colour, the workings were often described mistakenly as iron mines (see the OSM). In 1852, the German archaeologist Ludwig Ross published a book on his travels to Kos, Halikarnassos, Rhodes and Cyprus (Ross 1852; on his visit to Cyprus, see Mehl 2009), featuring a detailed account of the Skouriotissa mine. Ross recorded numerous mining galleries, one of which had collapsed, clearly killing someone whose remains were visible beneath the rubble (echoing Galen's description of regular accidents in the mine; see the OSM). Ross also recounts that as he moved up the hill the heap of black shiny slag was replaced by smaller heaps of red slag. Finally, he describes, in front of one of the mine entrances, a large assemblage of broken pottery with thick rounded feet, which he interpreted as crucibles or cooking pots. This must be the pottery dump described by Gunther, the prospector who rediscovered the copper ore deposit in 1912 (Lavender 1962). This dump of ceramic material also appears on the plans of the mine discussed below and in a photograph published by Bruce (1937). We now know that the dump comprised broken amphorae of a local type, which may have been used in the mine to bail water (Lavender 1962), to collect mineral-rich water that dripped from the walls of the galleries (important for the production of medications), or to provide water to the miners who worked underground (Jacobsen 2007; Kassianidou 2013a). Notably, all those who visited Skouriotissa in the eighteenth and nineteenth centuries (see the OSM) clearly state that the mine had long been abandoned. 


\section{Georeferencing ancient mining at Skouriotissa}

Largely unworked since late antiquity, the copper ore deposits of Cyprus were of great interest to the British Empire, which took control of the island in 1878. Kitchener's 1882 maps recorded some of the ancient slag heaps, providing useful information for ore prospectors (see the OSM). A later handbook produced by the Foreign Office details how the British Government wanted to develop the mining industry to alleviate the island's dependence on agriculture, compiling a list of mines worked during antiquity (Prothero 1920: 47). In 1921, the Colonial Office commissioned a report on the cupriferous deposits of the island (Cullis 1924), and an edited version was published in 1927 (Cullis \& Edge 1927). This report provides valuable information regarding the location of ancient slag heaps and mines in the foothills around the Troodos Mountains, and describes the state of the modern mining industry, which was still in its infancy during the early twentieth century. After a gap of a millennium, Skouriotissa was the only active mine on the island in the 1920s (worked by the Cyprus Mines Corporation).

When modern exploitation began at the Skouriotissa ore deposit, the miners invariably encountered ancient galleries and adits (Cullis \& Edge 1927; Bruce 1937). In some, they found wooden supports, ladders, ropes and even baskets, still well preserved due to the subterranean environment. Radiocarbon dates on well-preserved wooden supports show that mining at Skouriotissa dates back to at least the ninth century BC (Kassianidou 2013b).

Some of the earliest photographs, taken by Charles F. Jackson between 1923 and 1925, show ancient adits and the slag heaps (Everett 2017). The most detailed account of the ancient mining works, and their associated artefacts and slag heaps, was published in 1937 (Bruce 1937). This source remains the best and most detailed publication on ancient mining in Cyprus. The article includes three hand-drawn plans showing the location of ancient underground workings in relation to the outline of the Skouriotissa orebody. The information included in these plans, however, is not sufficiently accurate to geolocate these remains within the current landscape of the mining area. Cullis and Edge (1927) provide a more precise plan of the mine. The plan is highly detailed in that it not only includes contour lines representing elevations above sea level and the outline of the orebody, but also the drill holes undertaken by the mining company during exploration of the ore deposit, as well as the locations of some of the ancient remains included in Bruce's (1937) later plans. The key to enabling georeferencing of these plans is provided by Oskar Kortan, a mining engineer who worked for the Cyprus Mining Corporation. Between 1962 and 1964, Kortan produced accurate maps of Skouriotissa (Kortan 1970). These topographic maps include the location of all previous drill holes carried out by the Cyprus Mining Corporation and of buildings associated with the mining company, some of which still stand today. Using these buildings as geospatial control points, we have been able to rectify Kortan's map with the most recent high-resolution aerial orthophotograph of the area taken in 2014 by the Republic of Cyprus' Department of Lands and Surveys. As Kortan's map includes also some of the drill holes in Cullis and Edge's (1927) plan, we have also been able to georeference the 1927 plan. In turn, this has allowed us to geolocate remains indicated in Bruce's (1937) sketch. Figure 3 shows the result. Sadly, it is immediately evident that, a century later, most of these remains have 
been destroyed by the modern mining operations. Thus, Kortan's maps are of exceptional value for future studies of the ancient topography of Skouriotissa.

Fortunately, Kortan had a keen interest and respect for Cyprus' ancient cultural heritage. He painstakingly recorded with great accuracy the slag heaps, ancient adits and dumps - including the pottery assemblage (labelled as 'ancient bottle (pottery) dump' on Figure 4) - and many other remains, such as stone walls and features still visible in the 1960s. All of this spatial information has also been georeferenced and manually digitised (Figure 4). Kortan also recorded the exact location of 319 tombs-an entire necropolis. The location of the tombs has been georeferenced and superimposed over the 2014 aerial photograph (Figure 4). The necropolis forms a unique cluster in the southern part of the modern Skouriotissa open-cast mine, with all 319 tombs falling within a circle with a radius of less than $200 \mathrm{~m}$; the site now lies beneath the enormous leaching heaps where the ore is processed. As the tombs were not investigated before they were covered, nothing is known of their archaeological context. Nevertheless, circumstantial evidence suggests a Roman date (see the OSM).

\section{The Skouriotissa slag heap}

The most important ancient anthropogenic landmarks in the Skouriotissa area are the slag heaps (Figures $5-7 \mathrm{a} \& \mathrm{~b}$ ). They are without doubt among the largest ancient slag heaps known in Europe (Bourgarit 2019). When mining restarted in the twentieth century, copper ores were not smelted on the island, but were instead exported as concentrates (Constantinou 1992b). Thus, all of the slag at Skouriotissa, along with that found in more than 40 locations around the foothills of the Troodos mountain range (Figure 2) - estimated to have a volume of approximately four million tons — was produced during antiquity (Constantinou 1992a). The Skouriotissa slag heaps, together with those at the nearby Mavrovouni mine, are estimated to once have comprised around two million tons of slag (Bruce 1937): thus, approximately half of the copper ever produced on Cyprus in antiquity came from these two mines in the Solea Valley mining district.

Over the last 20 years, the remains of the slag heaps have been systematically investigated by two field projects involving the authors. First, the Troodos Archaeological and Environmental Survey Project (Given et al. 2013; Kassianidou 2013a) and, second, the Cyprus Archaeomagnetic Survey Project (Ben-Yosef et al. 2011; Shaar et al. 2015). Our current project has attempted to trace changes in the slag heaps through the twentieth to twenty-first centuries using aerial photographs and plans of the mine-changes due to systematic quarrying of slag, predominantly for road building and for cement manufacture, but also for export (Bear 1963; Given 2018). The expansion of the modern mine, the cutting of new access roads for large machinery, and the formation of modern spoil heaps have also contributed to the current diminished state of the ancient slag heaps.

When Gunther visited the area in 1912, he reported that the ancient slag heap overlooking the church measured approximately $800 \mathrm{~m}$ in length, $30-90 \mathrm{~m}$ in width and $20 \mathrm{~m}$ in height (Lavender 1962). Like Ross in 1852, Gunther also mentions the presence of two distinct types of slag — black and red—accumulated in separate heaps. On the basis of the spatial separation of the two slag types, the accumulation of red slags being higher up and closer to the ancient mining operations, and that the red slags were apparently the result of a less 


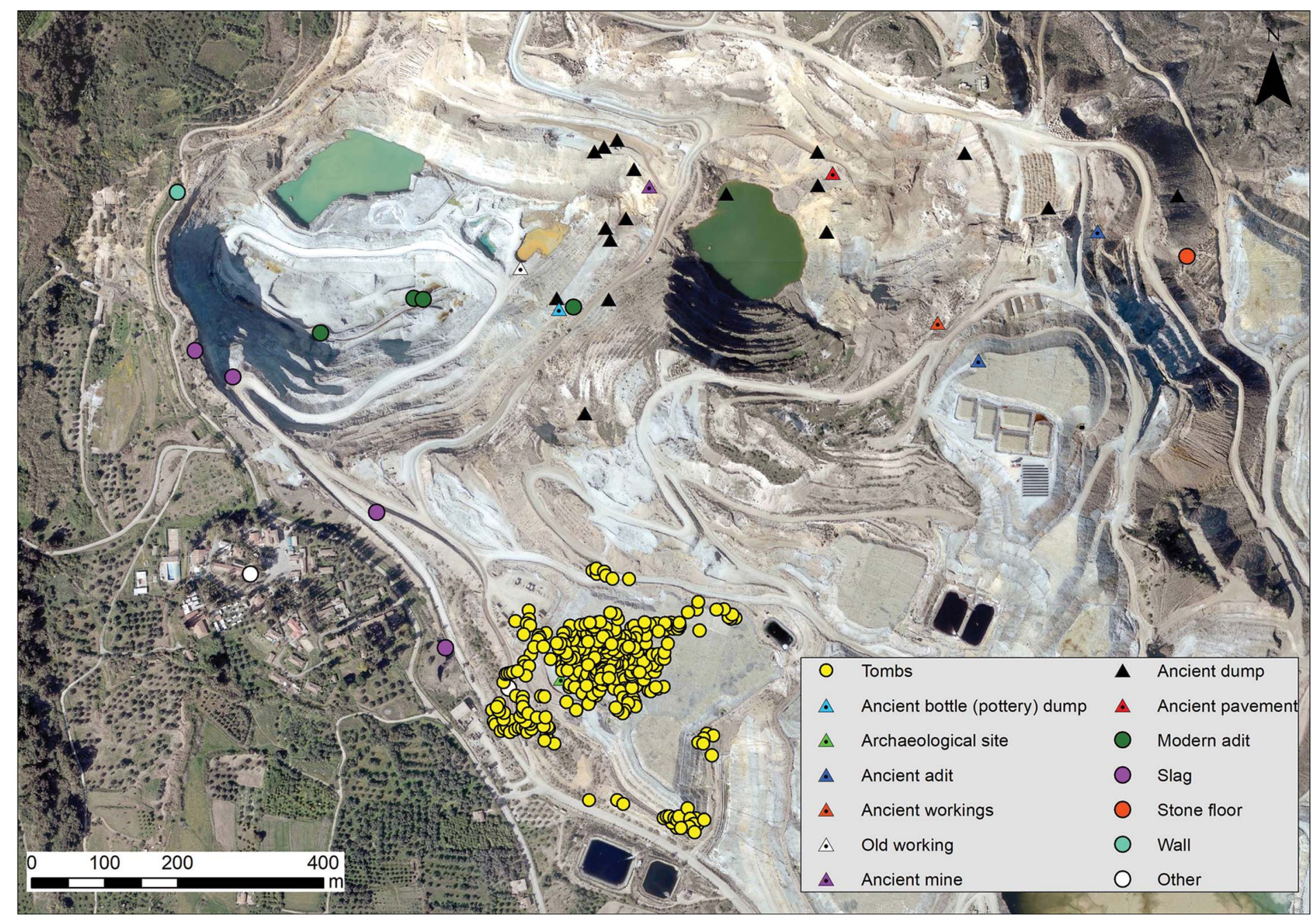

Figure 4. Places of archaeological interest noted on Kortan's (1970) map, overlaid on the 2014 aerial photograph of the area of Skouriotissa (figure by A. Agapiou; photograph courtesy of the Republic of Cyprus' Department of Lands and Surveys). 


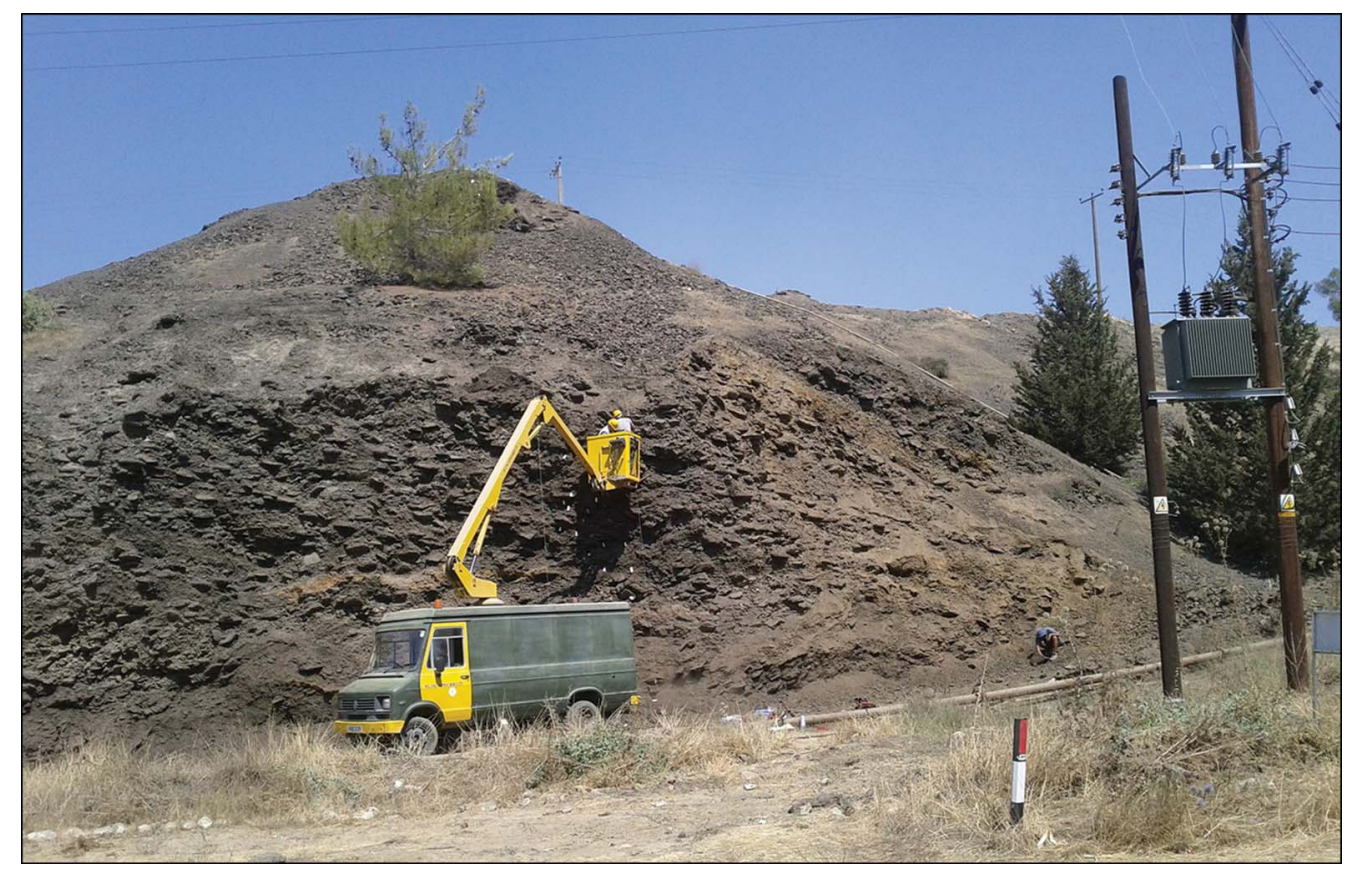

Figure 5. The Late Roman slag heap of Skouriotissa (photograph by V. Kassianidou, taken in 2011).

efficient smelting process, Gunther argued that the red slags were earlier in date, labelling them 'Phoenician' slags (Lavender 1962). The notion that the earliest mines were under Phoenician control dates to the nineteenth century (e.g. Rawlinson 1889), although there is little solid evidence to support direct Phoenician involvement in any aspect of the mining industry on Cyprus during the early first millennium BC.

As the Cyprus Mining Corporation had to buy or lease the land before beginning mining operations, a map of the Skouriotissa area was prepared in 1916. This map, discovered in the State Archives (SA 1/1036/1915), is published here for the first time, and shows the two spatially separated accumulations of slag (Figure 6). These are also visible in photographs from the 1930s found in Bruce's personal archive, one of which was published in his 1937 article (Figure 7a). The slag heaps feature prominently in Bruce's archive photographs of the annual sports day organised by the mining company (Figure 7b). In a 1957 aerial photograph by the Department of Lands and Surveys, the two heaps are clearly visible (Figure 8a). At that time, the mine was still worked using underground galleries, and the topography of the area had not yet been extensively modified. By 1970, when another aerial photograph was taken, opencast mining was well advanced, creating large spoil heaps (Figure $8 \mathrm{~b}$ ), which had completely covered the earlier (red) slag heap and had significantly reduced the extent of the larger (black) slag heap. The most recent (2014) aerial photograph provided by the Lands and Survey Department shows a completely altered industrial landscape and the larger (black) slag heap greatly reduced in size (Figure 8c). Overlaying the outlines of the slag heaps in 1950 and 1970 onto the 2014 photograph shows the scale of destruction (Figure 8d). 


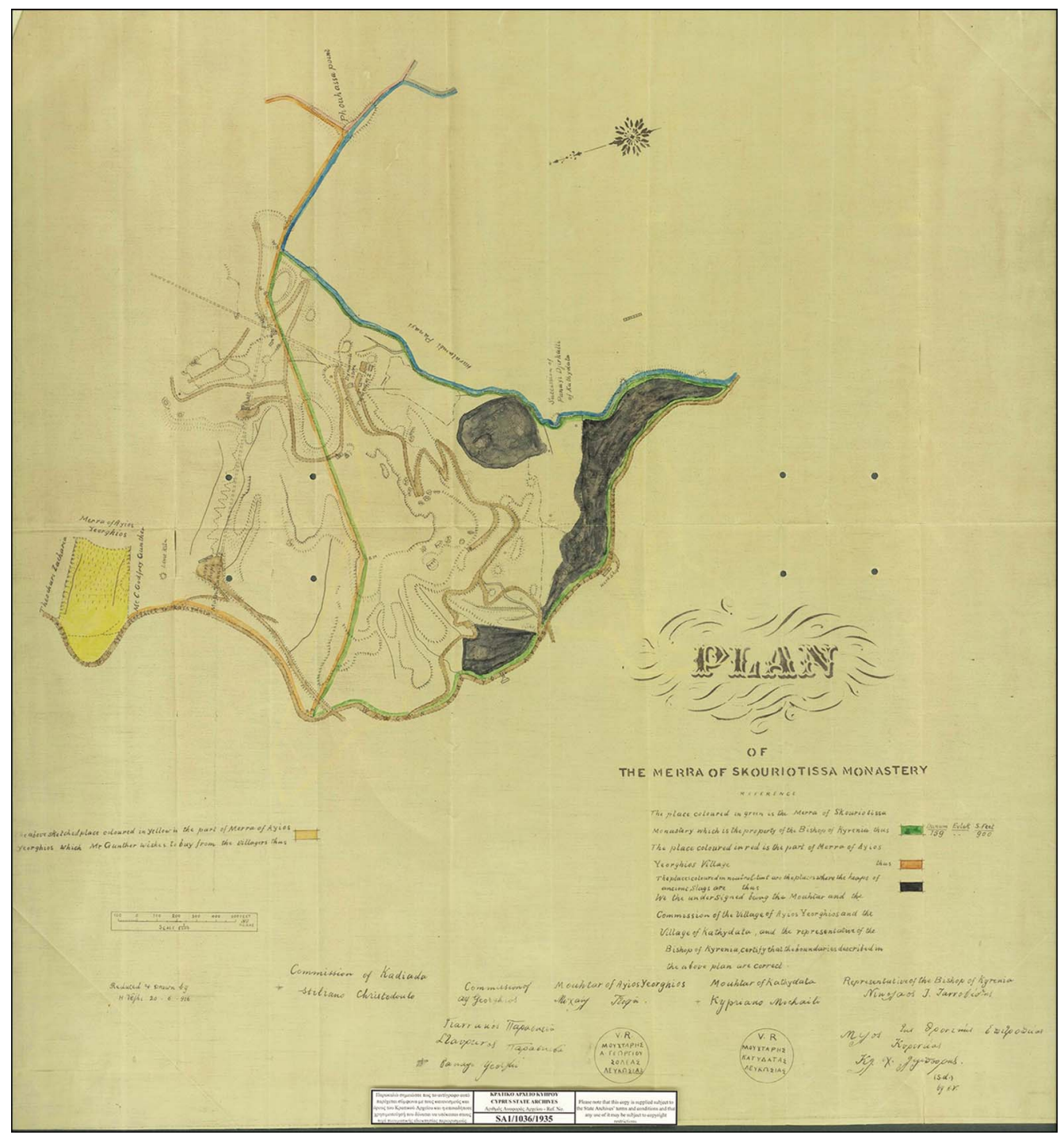

Figure 6. Map of the Merra of Skouriotissa Monastery showing the two slag heaps in 1916 (courtesy of the State Archives of Cyprus; SA1/1036/1915).

\section{Dating of the two slag heaps}

A key aim of recent research has been the absolute dating of the slag heaps and the smelting activities at Skouriotissa (for a description of the methodology, see Kassianidou 2004; Kassianidou 2013a; Shaar et al. 2015). As slag heaps are artificially produced over time, they are often stratified and can be dated either by associated pottery and other archaeological artefacts, or more precisely through radiocarbon dating of organic material collected from within the strata (Bachmann 1982: 6). As slag has been quarried during modern times by large machinery, there are large sections through the slag heap in which the stratigraphy is clearly 

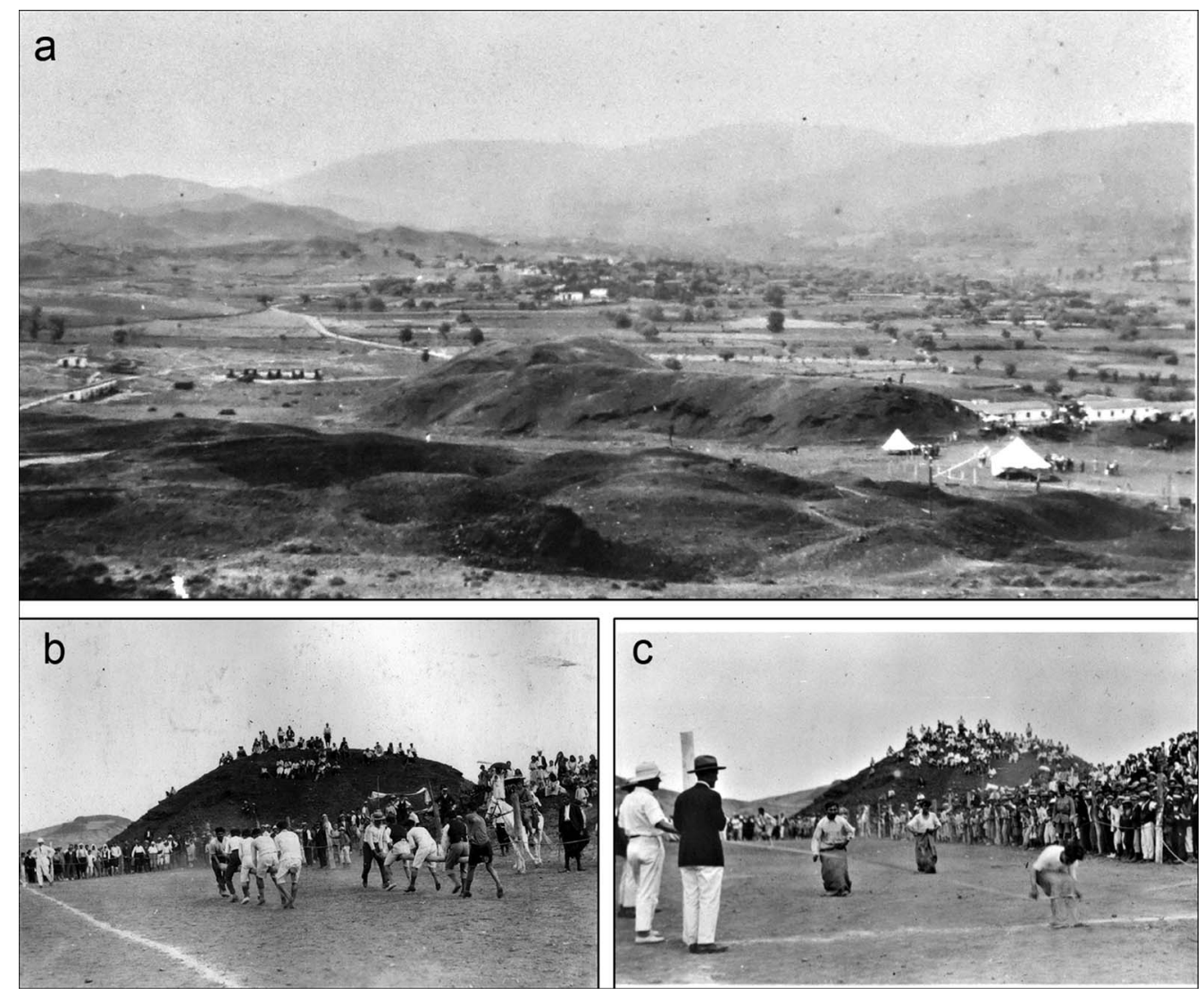

Figure 7. a) The Skouriotissa slag heap in 1929; b-c) sports day at Skouriotissa, March 1929 (photographs from the J.L. Bruce archive, courtesy of members of his family).

visible. Over the past 25 years, systematic recording and dating of slag heaps throughout Cyprus has been undertaken (Kassianidou 2004, 2013a; Manning 2013; Socratous et al. 2015). The most important result of this absolute dating is the conclusion that copper smelting had not ceased by the time of Galen's mid second-century BC visit (see the OSM) —as argued by several modern authors (e.g. Davies 1928-1930; Bruce 1937; Bear 1963). It is now clear, based on evidence from across the island, but especially from Skouriotissa (e.g. Kassianidou 2004, 2013a; Manning 2013), that the period of greatest activity of the Cypriot copper industry dates to the Late Roman/Early Byzantine period, in the fourth to seventh centuries $\mathrm{AD}$. This phenomenon relates directly to historical events in the Mediterranean region, when the Roman Empire was split into two during the fourth century AD. Following the division, Cyprus was under the jurisdiction of the Eastern Roman (Byzantine) Empire, which no longer had access to the copper mines of the Western Mediterranean or Central Europe. The gap in supply would have had to be filled by increasing production within the territories under the control of the Eastern Empire. Thus, copper production on the island in this period greatly intensified, reaching an unprecedented and truly industrial scale.

Extensive sampling of the largest exposed section of the black slag heap for radiocarbon dating was undertaken by the Cyprus Archaeomagnetic Project. With the help of Hellenic

(C) The Author(s), 2021. Published by Cambridge University Press on behalf of Antiquity Publications Ltd 

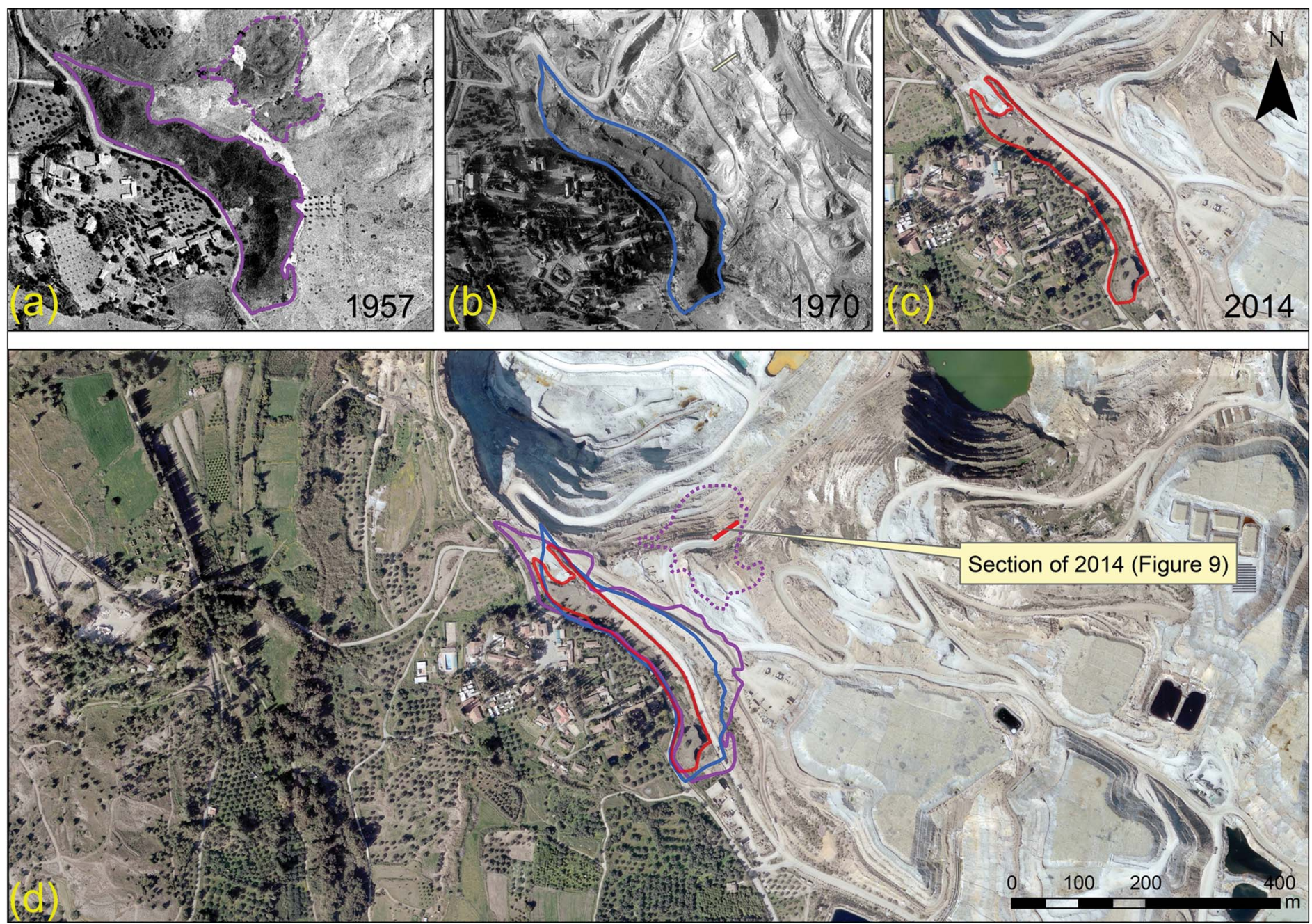

Figure 8. Collage of aerial photographs. The two slag heaps in a) 1957; b) 1970; c) 2014; d) combination of the outline of the slag heaps superimposed on the 2014 aerial photograph (figure by A. Agapiou; 1957, 1970 and 2014 aerial photographs courtesy of the Republic of Cyprus' Department of Lands and Surveys). 
Copper Mines - the company that currently holds the lease for Skouriotissa mine-we were able to reach even the lowest strata of the slag heap, and thus we have a full record of its stratigraphy. The previously published radiocarbon dates show that the exposed section of the slag heap formed $c$. AD 321-521, perhaps over as little as 50 years, or 200 years at the most (Shaar et al. 2015). The dates fit well with the typological study of pottery collected from this area of the slag heap (Kassianidou 2013a). Samples collected from other sections of the same slag heap also fall within an identical timeframe (Kassianidou 2013a; Manning 2013).

During the current project, we were able to apply absolute dating to the red (the putatively earlier) slag heap that was supposedly obliterated by the modern mining operations. In 2016, the mining company informed the authors that the remains of a slag heap had been revealed in the process of cutting a new road, and, with the permission of the Department of Antiquities of Cyprus, we duly recorded it. By plotting the location of the section on the aerial photograph (Figure 8), it is clear that this was indeed part of the red slag heap. With the help of heavy equipment provided by the mining company, we removed part of the road in order to reveal further lower levels. Although we did not reach the bottom of the section, the stratigraphy was documented using photogrammetry (Figure 9).

Six charcoal samples (four wood or wood charcoal, and two pinecone scales) were recovered from several layers in one part of the section (indicated in the lower part of Figure 9; see also Figure $10 \&$ Table S2). The radiocarbon results offer calibrated calendar dates between $172 \mathrm{BC}$ and $\mathrm{AD} 21$ (at 95.4\% probability, using OxCal v4.4.1 and IntCal20; Bronk Ramsey 2009a \& b; Reimer et al. 2020; Figure $10 \&$ Table S2). As the nature of the deposit suggests an associated set of discrete activities forming a phase within the slag heap (rather than separate events spread over a considerable period), we can model the dates as random events from within a uniform probability phase in OxCal, including outlier analysis and allowance for in-built age for the wood-charcoal samples. We can then query this model for the probable overall date-range estimate and the duration of activity represented (for details, see the OSM). Figure 10A shows the model and analysis. The date estimate (Figure 10B) indicates that the set of activities probably occurred between 73 and $26 \mathrm{BC}$ (62.6\% range within the $68.3 \%$ highest posterior density range), and the calendar duration involved is probably $0-79$ years (68.3\% highest posterior density) (Figure 10C). These dates place this activity either in the decades just before the annexation of Cyprus by Rome (from the Ptolemaic kingdom of Egypt) in 58 BC, or during the early decades of Roman control (on the evidence for Hellenistic and Roman mining in Cyprus, see Kassianidou 2000).

It should be pointed out that the absolute dates reported here for this section of the slag heap do not reflect the earliest mining phase at Skouriotissa, as the early aerial photographs reveal a great volume of slag higher up, closer to the ore deposit and mine. This was probably of an even earlier date, contemporaneous, perhaps, with the wooden mine supports, which have been dated to the Iron Age (Kassianidou 2013b).

\section{Conclusions}

Our analysis of disparate historical, archaeological and topographical data enables us to reconstruct the largely destroyed ancient mining landscape of Skouriotissa, the most important copper mine on the island of Cyprus and a key centre of copper production in the

(C) The Author(s), 2021. Published by Cambridge University Press on behalf of Antiquity Publications Ltd 


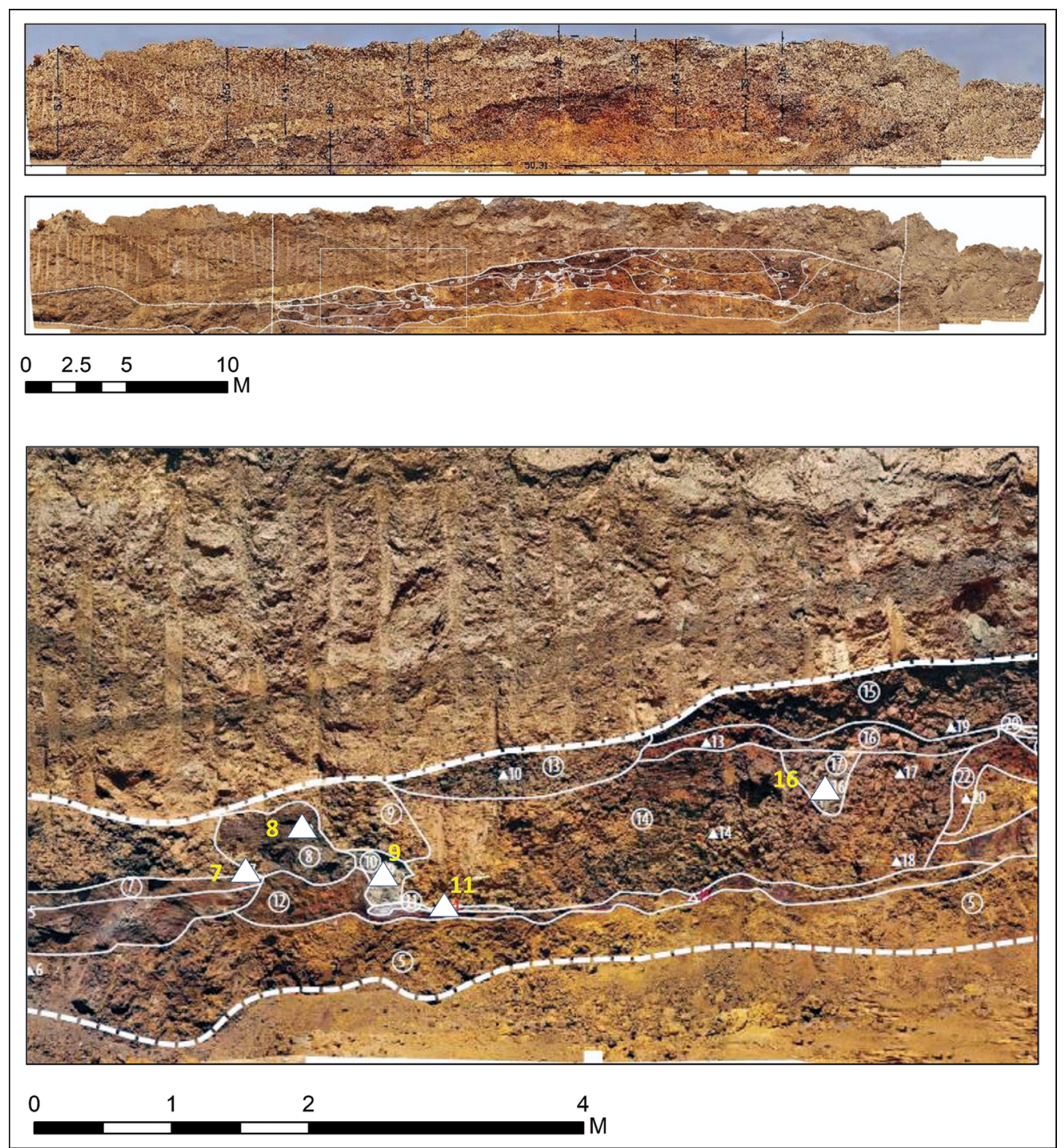

Figure 9. Section of the slag heap recorded in 2016, indicating the location of the samples used for radiocarbon dating (the location of the section is shown in Figure 8; figure by A. Agapiou \& A. Georgiadou).

ancient Mediterranean. By georeferencing, we have been able to reconstruct the location of ancient mining galleries and adits that were rediscovered and subsequently destroyed by modern mining operations relaunched in the 1910s, after more than a millennium of abandonment. To achieve this, we examined the personal archives of mining engineers who worked at Skouriotissa, as well as the Cyprus State Archives. These results show that ancient mining focused on the ore deposit of Phoukasa, which geological studies have shown to be very rich in copper (Bear 1963). An assemblage of mining tools and other equipment has been recovered from within these ancient galleries and adits, the publication of which is 


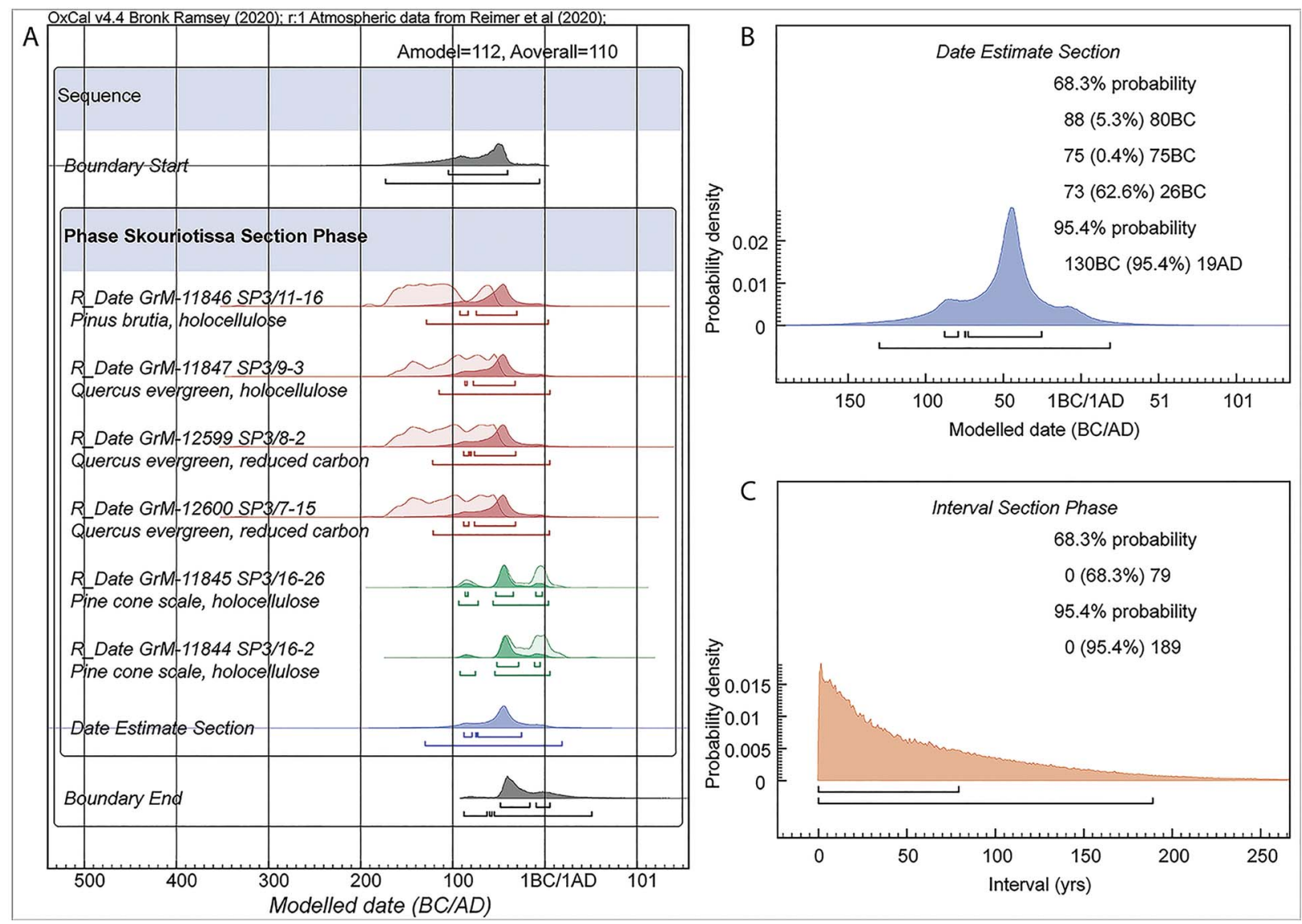

Figure 10. Radiocarbon dates from the slag heap section in Figure 9 (see Table S2) using OxCal v4.4.1 and IntCal20 (Bronk Ramsey 2009a \& b; Reimer et al. 2020): A) the six dates modelled as a uniform probability phase. Dates in brown are on woodlcharcoal and are assumed to include some in-built age (OxCal Charcoal Outlier model applied). Dates in green are on shorter-lived samples (pine cone scales) (OxCal General Outlier model applied). Light-shaded distributions indicate the non-modelled calibrated probabilities; dark distributions indicate the modelled posterior densities. The 68.3 per cent and 95.4 per cent ranges are indicated; B) the date estimate query from A; $C$ ) an interval query for the phase in A (for further explanation and references, see the OSM) (figure by S. Manning). 
forthcoming. Some of the supporting timber from the galleries has already been dated to the first half of the first millennium BC (Kassianidou 2013b) —a time when Cyprus was divided into city kingdoms, the wealth and prosperity of which depended on exploitation of the island's copper mines (Counts \& Iacovou 2013; Kassianidou 2013b). Some of the slag heaps-now no longer extant-would undoubtedly date to this period.

Absolute dating of a newly exposed section of a red slag heap that lies between Phoukasa and the Late Roman slag heap shows that extensive copper production also took place either during the Late Hellenistic period, when the island was part of the Ptolemaic kingdom of Egypt, or the Early Roman period following annexation of the island by Rome. The most intensive exploitation of this rich copper deposit, however, coincides with the Late Roman/Early Byzantine period. The truly impressive slag heap, a part of which is still extant, dates to this period.

The slag heaps of Skouriotissa once comprised two million tons of slag. Our analysis of historical aerial photographs has enabled us to trace the original extent of the slag heaps and, for the first time, to date part of the earlier red slag heap, thereby supplementing the chronological history of this key mining landscape. We have also been able to record the location of an ancient amphora dump, as well as the location of a previously unknown necropolis, both of which probably date to the Roman to Late Roman/Early Byzantine periods. We hope that our success in combining ancient topographical, archaeological and historical data, even when this initially seemed impossible, will form a pilot for understanding other mining regions of Cyprus and beyond.

\section{Acknowledgements}

The authors sincerely thank Oskar Kortan and the members of J.L. Bruce's family, who made their archives available to us. We would also like to thank Hellenic Copper Mines for assisting with fieldwork in Skouriotissa throughout our work. We thank Maria Socratous for wood identifications and the Republic of Cyprus' Department of Lands and Surveys for kindly providing the 1957, 1970 and 2014 aerial orthophotographs of the Skouriotissa area.

\section{Funding statement}

The project, Skouriotissa: Interdisciplinary Study of the Archaeology and Environment of Cyprus' Last Operating Copper Mine, was funded by a University of Cyprus A.G. Leventis Foundation Research Grant.

\section{Supplementary material}

To view supplementary material for this article, please visit https://doi.org/10.15184/aqy. 2021.33

\section{References}

Bachmann, H.-G. 1982. The identification of slags from archaeological sites (Institute of Archaeology Occasional Publication 6). London: Institute of Archaeology.
BEAR, L.M. 1963. The mineral resources and mining industry of Cyprus (Geological survey of Cyprus, Bulletin 1). Nicosia: Geological Survey Department, Ministry of Commerce and Industry.

(C) The Author(s), 2021. Published by Cambridge University Press on behalf of Antiquity Publications Ltd 
Ben-Yosef, E., R. Shatr, L. Tauxe, T. Levy \& V. Kassianidou. 2011. The Cyprus Archaeomagnetic Project (CAMP): targeting the slag deposits of Cyprus and the Eastern Mediterranean. Antiquity Project Gallery 85. Available at:

http://www.antiquity.ac.uk/projgall/benyosef330/ (accessed 3 March 2021).

Bourgarit, D. 2019. Mineralogy of slags: a key approach for our understanding of ancient copper smelting processes. EMU Notes in Mineralogy 20: 203-31. https://doi.org/10.1180/EMU-notes.20.5

Bronk Ramsey, C. 2009a. Bayesian analysis of radiocarbon dates. Radiocarbon 51: 337-60. https://doi.org/10.1017/S0033822200033865

- 2009b. Dealing with outliers and offsets in radiocarbon dating. Radiocarbon 51: 1023-45. https://doi.org/10.1017/S0033822200034093

BruCE, J.L. 1937. Appendix V: antiquities in the mines of Cyprus, in E. Gjerstad, J. Lindros, E. Sjoqvist \& A. Westholm (ed.) The Swedish Cyprus expedition: finds and results of the excavations in Cyprus 1927-1931, volume III: 639-71. Stockholm: Swedish Cyprus Expedition.

Constantinou, G. 1982. Geological features and ancient exploitation of the cupriferous sulphide orebodies of Cyprus, in J.D. Muhly, R. Maddin \& V. Karageorghis (ed.) Early metallurgy in Cyprus 4000-500 BC: 13-23. Larnaca: Pierides Foundation.

- 1992a. Ancient copper mining in Cyprus, in A. Marangou \& K. Psillides (ed.) Cyprus copper and the sea: 44-75. Nicosia: Government of Cyprus.

- 1992b. The mining industry of Cyprus in modern times, in A. Marangou \& K. Psillides (ed.) Cyprus copper and the sea: 328-67. Nicosia: Government of Cyprus.

Counts, D.B. \& M. Iacovou. 2013. New approaches to the elusive Iron Age polities of ancient Cyprus: an introduction. Bulletin of the American Schools of Oriental Research 370: 1-13. https://doi.org/10.5615/bullamerschoorie.370. 0001

Cullis, C.G. 1924. A sketch of the geology and mineral resources of Cyprus. Journal of the Royal Society of Arts 72: 624-47.

Cullis, C.G. \& A.B. Edge. 1927. Report on the cupriferous deposits of Cyprus. London: Crown Agents for the Colonies.
Davies, O. 1928-1930. The copper mines of Cyprus. Annual of the British School at Athens 30: 74-85. https://doi.org/10.1017/S0068245400011497

Everett, W.J. 2017. Mining memories on Cyprus 1923-1925: photographs, correspondence and reflections. Kindle Edition.

Given, M. 2018. The materiality, monumentality and biography of copper slag on Cyprus, in L. Nevett \& J. Whitley (ed.) An age of experiment: Classical archaeology transformed (1976-2014): 161-76. Cambridge: McDonald Institute for Archaeological Research.

Given, M., A.B. Knapp, L. Sollars, J. Noller \& V. Kassianidou. 2013. Landscape and interaction: the Troodos Archaeological \& Environmental Survey Project, Cyprus (volumes 1-2) (Levant Supplementary Series 14-15). Oxford: Council for British Research in the Levant \& Oxbow.

Healy, J.F. 1978. Mining and metallurgy in the Greek and Roman world. London: Thames \& Hudson.

IngHAM, F.T. 1959. Economic geology, in R.A.M. Wilson (ed.) The geology of the Xeros-Troodos area (Geological Survey Department Cyprus Memoir 1): 137-77. Nicosia: Geological Survey Department.

Jacobsen, K.W. 2007. Transport amphorae in the copper mining industry of Cyprus: introducing a new type of transport amphorae from Cyprus, in M. Bonifay \& J.-C. Treglia (ed.) LRCW 2: Late Roman coarse wares, cooking wares and amphorae in the Mediterranean: archaeology and archaeometry, volume II (British Archaeological Reports International Series 1662): 775-79. Oxford: British Archaeological Reports.

Kassianidou, V. 2000. Hellenistic and Roman mining in Cyprus, in G.K. Ioannides \& S.A. Hadjistyllis (ed.) Acts of the third International Congress of Cypriot Studies, Nicosia, 16-20 April 1996. Volume A: ancient section: 745-56. Nicosia: Society of Cypriot Studies.

- 2004. Recording Cyprus' mining history through archaeological survey, in M. Iacovou (ed.) Archaeological field survey in Cyprus: past history, future potential. Proceedings of a conference held by the Archaeological Research Unit of the University of Cyprus, 1-2 December, 2000: 95-104 (British School at Athens Studies 11). London: British School at Athens. 
- 2013a. Ancient and modern copper production at Skouriotissa Vouppes, in M. Given, A.B. Knapp, L. Sollars, J. Noller \& V. Kassianidou (ed.) Landscape and interaction: the Troodos Archaeological \& Environmental Survey Project, Cyprus (volume 2) (Levant Supplementary Series 14-15): 114-38. Oxford: Council for British Research in the Levant \& Oxbow.

$-2013 \mathrm{~b}$. The exploitation of the landscape: metal resources and the copper trade during the age of the Cypriot city-kingdoms. Bulletin of the American School of Oriental Research 370: 49-82. https://doi.org/10.5615/bullamerschoorie.370. 0049

Kassianidou, V. \& G. Papasavvas. 2012. Eastern Mediterranean metallurgy and metalwork in the second millennium $B C$ : a conference in honour of James D. Mubly. Oxford: Oxbow. https://doi.org/10.2307/j.ctvh1dvpm

Kortan, O. 1970. Zur Bildung der Schwefelkies-Kupferkies-Vorkommen Cyperns unter besonderer Berücksichtigung der Lagerstätte Skouriotissa. Unpublished PhD Dissertation, Technischen Universitat Clausthal.

Lavender, D.S. 1962. The story of the Cyprus Mines Corporation. Los Angeles (CA): Huntingdon Library.

Manning, S.W. 2013. Absolute dating of charcoal samples from the slag heaps, in M. Given,

A.B. Knapp, L. Sollars, J. Noller \&

V. Kassianidou (ed.) Landscape and interaction: the Troodos Archaeological \& Environmental Survey Project, Cyprus (volume 1) (Levant Supplementary Series 14): 48-54. Oxford: Council for British Research in the Levant \& Oxbow.

Merl A. 2009. Der Archäologe Ludwig Ross 1845 in Zypern auf den Spuren der Antike, in S. Rogge (ed.) Zypern und der Vordere Orient im 19. Jahrhundert: die Levante im Fokus von Politik und Wissenschaft der europäischen Staaten. Symposium, Münster 27.-28. Oktober 2006: 153-87.

Munster: Waxmann.

Muhly, J.D., R. Maddin \& V. Karageorghis (ed.). 1982. Early metallurgy in Cyprus 4000-500 $B C$. Larnaca: Pierides Foundation.
O'Brien, W. 2015. Prehistoric copper mining in Europe 5500-500 BC. Oxford: Oxford University Press.

Prothero, G.W. 1920. Cyprus (Handbooks Prepared Under the Direction of the Historical Section of the Foreign Office 65). London: H.M. Stationery Office.

Rawlinson, G. 1889. History of Phoenicia. London: Longmans, Green \& Co.

Reimer, P.J. et al. 2020. The IntCal20 Northern Hemisphere radiocarbon age calibration curve (0-55 kcal BP). Radiocarbon 62: 725-57. https://doi.org/10.1017/RDC.2020.41

Ross, L. 1852. Reise nach Kos, Halikarnassos, Rhodes und Cypern. Halle: CA Schwetschke \& Sohn.

Shatr, R., L. Tauxe, E. Ben-Yosef,

V. Kassianidou, B. Lorentzen, J.M. Feinberg \& T.E. Levy. 2015. Decadal-scale variations in geomagnetic field intensity from ancient Cypriot slag mounds. Geochemistry, Geophysics, Geosystems 16: $1-20$. https://doi.org/10.1002/2014GC005455

SHIRLEY, R. 2001. Kitchener's survey of Cyprus 18781883: the first full triangulated survey and mapping of the island. Nicosia: The Bank of Cyprus Cultural Foundation.

Socratous, M.A., V. Kassianidou \& G. Di Pasquale. 2015. Ancient slag heaps in Cyprus: the contribution of charcoal analysis to the study of the ancient copper industry, in A. Hauptmann \& D. Modarressi-Tehrani (ed.) Archaeometallurgy in Europe III: proceedings of the third International Conference, Deutsches Bergbau-Museum Bochum, June 29-July 1, 2011 (Der Anschnitt, Beiheft 26): 377-84. Bochum: Deutches Bergbau Museum.

STÖLLNER, T.R. 2014. Methods of mining archaeology (Montanarchäologie), in B.W. Roberts \& C.P. Thornton (ed.) Archaeometallurgy in global perspective: 91-105. New York: Springer. https://doi.org/10.1007/978-1-4614-9017-3_7

Wallace, P.W. \& A.G. Orphanides. 1990. Sources for the history of Cyprus. Volume I: Greek and Latin texts to the third century $A D$. Albany $(\mathrm{NY})$ : The Institute of Cypriot Studies, University at Albany, State University of New York \& Cyprus College.

(C) The Author(s), 2021. Published by Cambridge University Press on behalf of Antiquity Publications Ltd 